\title{
Karakteristik Pelaku Usaha Ikan Asin di Muara Angke
}

\section{Characteristics of Salted Fish Business in Muara Angke}

\author{
Nurfiqayumi Arnis ${ }^{1)}$, Burhanuddin'), Wahyu Budi Priyatna ${ }^{3)}$ \\ 1) Magister Agribisnis Institut Pertanian Bogor \\ ${ }^{2) 3)}$ Departemen Agribisnis Institut Pertanian Bogor \\ E-mail: nurfiqayumiarnis@gmail.com
}

\begin{abstract}
This study aims to analyze the characteristics of salted fish business in Muara Angke. This research was conducted in Muara Angke, North Jakarta, namely salted fish business. The salted fish business in Muara Angke is the largest fish and fish processing center in Jakarta. Data analysis in this research is qualitative and quantitative. Qualitative analysis using descriptive method to describe the characteristics of salted fish business in Muara Angke. The results revealed that the characteristics of salted fish business in Muara Angke in general, among others: (1) The majority of businessmen of male sex and salted fish processing business is the main livelihood; (2) The education level of the majority of elementary school graduates; (3) they have sufficient experience in the processing of salted fish, (4) their income is mostly able to fulfill their daily needs (5) The business capital is obtained as personal capital; (6) the standard of living and welfare of salted fish farmers in general is still low, due to the small scale of business, and the majority of salted fish business is oriented only on the fulfillment of daily needs.
\end{abstract}

Keywords: characteristic, salted fish, UMKM

Diterima: 20 Agustus 2018. / Disetujui: 9 Mei 2019

\section{PENDAHULUAN}

Kinerja usaha merupakan salah satu tolak ukur dari perilaku kewirausahaan sehingga adanya konsep perilaku kewirausahaan pada pelaku usaha merupakan hal yang penting, karena akan berdampak pada kinerja usaha. Pengembangan perilaku kewirausahaan akan menumbuhkan sikap positif dalam berwirausaha dalam bentuk kemampuan sikap untuk mengendalikan keadaan dan memfokuskan perhatian pada kegiatan-kegiatan atau hasil yang ingin dicapai (Krisnamurthi, 2001). Hal ini disebabkan pelaku usaha yang berperilaku kewirausahaan akan lebih aktif dalam memanfaatkan peluang, inovatif dan berani mengambil risiko. Salah satu pelaku usaha yang dapat memanfaatkan peluang dan berani mengambil risiko yakni usaha mikro kecil dan menengah (UMKM).

Di Indonesia UMKM hampir sebagian besar menguasai sektor usaha, khususnya bidang pertanian, perikanan, dan peternakan. Kehadiran UMKM dapat menjadi pemicu masyarakat untuk 
selalu berfikir ke arah usaha yang bersifat kewrirausahaan. Dengan adanya sifat kewirausahaan dalam diri seseorang mampu mengeksplorasi individu tersebut mengarah pada pemanfaatan peluang (Krueger, Reilly and Carsrud, 2000). Sehingga sangat penting untuk mengembangkan kewirausahaan karena dapat menjadi ukuran kemajuan suatu negara. Semakin banyak sikap kewirausahaan yang tumbuh dalam diri masyarakat maka peningkatan ekonomi suatu negara akan semakin tinggi.

Salah satu industri yang juga memegang peranan dalam sektor pertumbuhan ekonomi yakni industri dalam sektor pengolahan yang umumnya masih berada dalam skala usaha mikro, kecil dan menengah. Berdasarkan tabel 1 bahwa data dari Kementerian Koperasi dan UKM ini terlihat jumlah pelaku UMKM merupakan pelaku ekonomi dominan yang mencapai 58000000 juta unit atau 99,99\% dari seluruh pelaku ekonomi nasional sehingga hal ini mampu memberikan penyerapan tenaga kerja yang bekerja di sektor UMKM sehingga memberikan solusi lapangan pekerjaan dan mampu berkontribusi terhadap pembentukan produk domestik bruto (PDB). Selain itu, industri mikro dan kecil menyumbang pembangunan dengan berbagai jalan, menciptakan kesempatan kerja, dan menyediakan fleksibilitas kebutuhan serta inovasi dalam perekonomian secara keseluruhan (Partomo TS, 2002).

Masalah-masalah yang terjadi dalam usaha ikan asin ini merupakan tugas pemilik usaha atau pelaku usaha untuk mengatasinya. Dimana pemilik usaha itu merupakan pelaku utama dalam pengusahaan ikan asin. Penyediaan sumberdaya manusia yang kompeten juga penting di dalam usaha pengolahan asin.

Kewirausahaan harus dikembangkan sebagai modal agar pelaku usaha dan masyarakat mampu mandiri dan berhasil dalam usahanya. Pengembangan sumberdaya manusia juga menjadi salah satu kunci dalam menjawab permasalahan ini karena pada era global saat ini dibutuhkan pelaku usaha yang kreatif dan inovatif agar mampu bertahan dan bersaing. Faktor kewirausahaan menentukan berhasil tidaknya pelaku usaha dalam menyesuaikan dengan perubahan lingkungan bisnis. Seorang wirausaha juga harusmampu mempertimbangkan aspek pasar, mampu melihat dan mengelola peluang, serta memiliki kemampuan manajemen yang baik. Selain itu pentingnya peran sumberdaya manusia dalam pencapaian keunggulan kompetitif yaitu faktor manusia menjadi faktor yang sangat menentukan keberhasilan pencapaian keunggulan kompetitif, karena pada manusia akan diperoleh kreativitas dan inovasi, pada manusia juga melekat kemampuan dan keberanian serta sikap memanfaatkan peluang dan mengatasi kesulitan (Krisnamurthi, 2001). Penguasaan dan pemanfaatan teknologi juga akan terletak pada manusia, disamping kemampuan untuk mendapatkan modal, informasi dan jaringan usaha.

Berdasarkan pemaparan di atas dapat dikatakan bahwa masih rendahnya kinerja usaha ikan asin dipengaruhi oleh faktor sumberdaya manusia yang ditinjau dari perilaku kewirausahaannya, sehingga masalah yang akan diteliti adalah Bagaimana karakteristik pelaku usaha ikan asin di Muara Angke? 


\section{METODE PENELITIAN}

Penelitian ini dilaksanakan di Muara Angke, Jakarta Utara yaitu pada usaha ikan asin. Usaha ikan asin yang ada di Muara Angke merupakan sentra pelelangan ikan dan pengolahan ikan terbesar di Jakarta. Penentuan loaksi dilakukan secara purposive yaitu dengan pertimbangan lokasi ini merupakan sentra industri ikan asin di Jakarta. Penelitian ini akan dilaksanakan pada bulan Juni sampai dengan Juli 2017.

Jenis data yang digunakan dalam penelitian ini adalah data primer dan data sekunder. Data primer diperoleh dengan melakukan observasi serta wawancara kepada responden di lokasi penelitian dengan menggunakan kuisioner berskala likert 5 poin. Sedangkan data sekunder diperoleh dari Badan Pusat Statistik (BPS), Unit Pengelola Pelabuhan Dinas Kelautan Pertanian dan Ketahanan Pangan Provinsi DKI Jakarta.

Analisis data dalam penelitian ini yaitu secara kualitatif dan kuantitatif. Analisis kualitatif menggunakan metode deskriptif untuk menggambarkandan menjabarkan karakteristik pelaku usaha ikan asin di Muara Angke. Data yang dianalisis secara deskriptif disajikan dalam suatu alinea uraian secara naratif yang mampu menggambarkan tentang karakteristik pelaku usaha ikan asin di Muara Angke.

\section{HASIL DAN PEMBAHASAN}

\section{Karakteristik Individu, Lingkungan, Perilaku Kewirausahaan dan Kinerja Usaha}

\section{Skor Indikator Faktor IndividuPada Usaha Pengolahan Ikan Asin}

Faktor individu pelaku usaha ikan asin merupakan atribut yang melekat pada sifat dan kualitas pribadi atau personal yang diperlihatkan dalam menjalankan usahanya. Berdasarkan hasil penelitian pada Tabel 1, dapat dinyatakan bahwa pada umumnya responden pelaku usaha ikan asin dalam menjawab pertanyaan pada kusioner yang dikategorikan berdasarkan tiga tingkatan terhadap indikator faktor individu yang diukur dari pengalaman, percaya diri, motivasi, keterampilan, persentase terhadap usaha dan keinginan untuk mengusahakan usaha pengolahan ikan asin.

Tabel 1 Penilaian pelaku usaha ikan asin terhadap faktor individu

\begin{tabular}{|c|c|}
\hline Variabel Indikator & Rataan \\
\hline Pengalaman $(\mathrm{X} 1.1)$ & 3,76 \\
\hline Percaya Diri (X1.2) & 4,27 \\
\hline Motivasi(X1.3) & 3,97 \\
\hline Keterampilan (X1.4) & 4,15 \\
\hline Persentase terhadap usaha (X1.5) & 3,77 \\
\hline
\end{tabular}


Keinginan berusaha (X1.6) 4,07

Keterangan: Rendah 1-2.33, Sedang 2.34-3.66, Tinggi 3.67 - 5

Pengalaman dalam menjalankan usaha murupakan modal yang penting bagi seorang pelaku usaha dan menjadi hal yang penting dalam menjalankan usaha karena seorang pelaku usaha yang memiliki pengalaman berusaha dalam waktu lama akan semakin terampil dalam menghadapi tantangan dan masalah dalam menjalankan usahanya.Variabel indikator pengalaman (X1.1) pada faktor individu berada pada kategori tinggi dengan nilai rataan 3.76, hal ini menunjukkan bahwa mayoritas pelaku usaha dalam menjalankan usahanya dan melakukan proses produksi berdasarkan dari pengalaman yang didapatkan. Berdasarkan keadaan di lapangan mayoritas pelaku usaha juga menjalankan usaha karena kebutuhan hidup bukan karena berdasarkan orientasi bisnis, sehingga pengalaman yang banyak didapatkan pelaku usaha seiring dengan berjalannya usaha. Selain itu beberapa responden menjalankan usaha pengolahan ikan asin berdasarkan pada pengalaman yang sebelumnya, artinya dalam menjalankan usaha ikan asin umumnya merupakan usaha turun temurun, sehingga membuat mereka berminat dalam menjalankan usaha tersebut. Responden yang memiliki pengalaman yang banyak dalam melakukan proses pengolahan ikan asin diperoleh melalui bimbingan sejak kecil yang diberikan oleh orang tua yang berprofesi sebagai pelaku usaha ikan asin. Hal ini dikarenakan dalam proses pembuatan ikan asin tidak dapat dilakukan secara asal-asalan tetapi perlu pengalaman yang cukup nntuk menghasilkan ikan asin yang berkualitas baik.

Salah satu tolak ukur keberhasilan usaha dipengaruhi oleh faktor individu tersebut dimana rasa percaya diri dalam diri seseorang juga merupakan modal untuk memulai suatu usaha. Percaya diri dalam penelitian ini diukur melalui keyakinan seorang pelaku usaha untuk memulai dan menjalankan usahanya dan memiliki keyakinan bahwa berani menentukan target kerja dan mendapatkan keuntungan. Berdasarkan hasil penelitian pengumpulan data dari para pelaku usaha ikan asin variabel indikator percaya diri (X1.2) berada pada kategori tinggi yakni dengan nilai rataan 4.27, artinya rasa percaya diri pelaku usaha ikan asin dalam menjalankan usahanya tinggi sehingga tidak sulit untuk memulai usaha ini. Hal ini menunjukkan bahwa pelaku usaha ikan asin di Muara Angke memulai usaha dengan rasa percaya diri yang tinggi akan keuntungan dan keberhasilan usaha yang akan diperolehnya, sehingga sampai saat ini masih banyak pelaku usaha yang bertahan dalam menjalan usaha pengolahan ikan asin di Muara Angke.

Motivasi seseorang menjadi wirausaha dapat karena keterpaksaan atau cita-cita. Namun keduanya didasari oleh motivasi untuk memenuhi kebutuhan hidup dari segi finansial baik untuk keluarga atau diri sendiri, memberikan pendidikan untuk anak-anaknya, serta meningkatkan status sosial. Selain itu, bagi seorang pelaku usaha motivasinya tidak hanya karena faktor finansial saja tetapi juga kebutuhan untuk berprestasi untuk menjadi wirausaha sukses dan keinginan untuk tidak terikat oleh suatu perusahaan atau karena waktunya yang lebih bebas jika menjalankan suatu usaha serta motivasi dalam berusaha dikarenakan ingin meneruskan usaha keluarganya. Menjadi seorang 
wirausaha merupakan pilihan atas dasar kebutuhan yang didukung oleh suatu dorongan untuk memenuhi kebutuhan tersebut kemudian dilaksanakan dengan tindakan yang dapat menghasilkan kepuasan. Berdasarkan hasil penelitian pengumpulan data dari para pelaku usaha ikan asin variabel indikator motivasi (X1.3) berada pada kategori tinggi dengan nilai rataan sebesar 3.97, artinya motivasi pelaku usaha dalam menjalankan usaha pengolahan ikan asin tinggi. Hal ini berdasarkan kenyataan di lapangan bahwa mayoritas pelaku usaha ikan asin di Muara Angke memiliki motivasi dalam menjalankan usaha tinggi dikarenakan faktor finansial atau motivasi untuk memenuhi kebutuhan hidup saja. Meskipun masih banyak pelaku usaha yang melum memiliki motivasi usaha kearah bisnis dikarenakan modal yang belum cukup untuk memperbesar skala usaha. Adapun pelaku usaha yang sudah memiliki orientasi bisnis atau laba karena usaha yang dijalankan adalah usaha turuntemurun yang jumlah produksi hariannya dapat mencapai 10 ton sehingga motivasi berusaha sudah pada tingkat orientasi bisnis dan keuntungan yang diperoleh melebihi kebutuhan hidup.

Keterampilan merupakan salah satu unsur penting di balik keberhasilan usaha dimana keterampilan seorang pelaku usaha dapat diukur melalui kemampuan pelaku usaha dalam memanfaatkan sumberdaya yang tersedia, mampu mendapatkan bahan baku yang baik dan murah serta mampu untuk mengenali pasar khusus dan mengembangkan suatu usahanya di pasar tersebut. Dengan demikian para pelaku usaha ikan asin harus mampu memanfaatkan segala sumberdaya yang ada disekitarnya. Variabel indikator keterampilan (X1.4) berada pada kategori tinggi dengan nilai rataan sebesar 4.15, artinya keterampilan pelaku usaha dalam menjalankan usaha pengolahan ikan asin tinggi karena para pelaku usaha ikan asin di Muara Angke mampu memanfaatkan sumberdaya yang ada disekitarnya untuk keberlanjutan dan keberhasilan usaha mereka. Selain itu mayoritas pelaku usaha memilih bahan baku yang baik dan mengetahui tempat mendapatkan bahan baku yang baik dan murah.

Persentase pelaku usaha terhadap keberhasilan usahanya (X1.5) diukur melalui peningkatan produksi secara bertahap dan dalam melakukan usaha pengolahan ikan asin memakan waktu yang cukup lama atau tidak. Indikator persentase pelaku usaha pada faktor individu berada pada kategori tinggi dengan rataan 3.77, artinya pelaku usaha dalam menjalankan usaha dapat meningkatkan hasil produksinya sehingga mampu meningkatkan skala usaha dapat bertambah. Akan tetapi meskipun data menunjukkan persentase pelaku usaha berasa pada kategori tinggi namun berdasarkan kenyataan dilapangan masih banyak pelaku usaha yang produksinya tidak terus meningkat sehingga belum mampu meningkatkan skala usahanya. Mayoritas pelaku usaha menganggap bahwa keberhasilan usaha ini memakan waktu yang cukup lama serta peningkatan produksi yang terjadi secara bertahap juga memakan waktu yang cukup lama sesuai dengan modal yang mereka miliki. 
Keinginan berusaha pengolahan ikan asin diukur melalui seberapa besar keinginan pelaku usaha untuk terus berusaha dan mempertahankan usahanya. Variabel indikator keinginan berusaha (X1.6) pada faktor individu berada pada kategori tinggi dengan nilai rataan 4.07, artinya mayoritas keinginan pelaku usaha untuk terus berusaha dan mempertahankan usahanya masih tergolong tinggi, hal ini disebabkan adanya dorongan dari keluarga untuk dapat memenuhi kebutuhan sehari-hari melalui usaha pengolahan ikan asin di Muara Angke yang menyebabkan pelaku usaha bertahan. Selain itu pelaku usaha ikan asin juga masih memiliki keyakinan yang penuh terhadap keberhasilan usahanya sehingga mereka masih tetap mempertahankan usaha mereka meskipun memiliki tantangan yang besar kedepannya.

Secara umum faktor individu merupakan karakteristik individu dari rata-rata responden dapat dikatakan baik untuk menjadi wirausaha. Hal ini merujuk pada hasil nilai rataan pada indikator variabel individu semua berada pada kategori tinggi, yang menunjukkan bahwa besarnya kontribusi faktor individu pelaku usaha ikan asin di Muara Angke dalam menjalankan usaha.

\section{Skor Indikator Faktor Lingkungan PadaUsaha Pengolahan Ikan Asin}

Faktor lingkungan merupakan faktor penyebab perilaku yang terdapat dalam lingkungan atau situasi seseorang melakukan suatu usaha. Pada Tabel 2 dapat dilihat kategori penilaian pelaku usaha terhadap indikator-indikator faktor lingkungan yang diukur dari ketersediaan bahan baku, dukungan penyuluhan dan pelatihan, bantuan modal, dukungan pemerintah serta kekompakan antar pelaku usaha.

Tabel 2 Penilaian pelaku usaha ikan asin terhadap faktor lingkungan

\begin{tabular}{ll}
\hline \multicolumn{1}{c}{ Variabel Indikator } & Rataan \\
\hline Ketersediaan bahan baku (X2.1) & 3,85 \\
Dukungan penyuluhan dan Pelatihan (X2.2) & 2,13 \\
Bantuan Modal (X2.3) & 2,09 \\
Dukungan pemerintah (X2.4) & 2,97 \\
Kekompakan antar pelaku usaha (X2.5) & 3,88 \\
\hline \multicolumn{1}{c}{ Keterangan: Rendah 1-2.33, Sedang 2.34-3.66, Tinggi 3.67-5 }
\end{tabular}

Keterangan: Rendah $1-2.33$, Sedang $2.34-3.66$, Tinggi 3.67 - 5

Ketersediaan bahan bahan baku seperti ikan mentah dan garam selama ini dianggap relatif mudah didapatkan meskipun harga ikan yang pada waktu tertentu relatif mahal. Namun pada Mei hingga Agustus 2017 harga bahan baku garam meningkat secara drastis dimana harga pada biasanya 40.000,- hingga 50.000,- per $50 \mathrm{~kg}$, pada waktu tersebut harga garam mencapai 250,000,- per $50 \mathrm{~kg}$. Akan tetapi hal tersebut bukan menjadi penghalang bagi pelaku usaha ikan asin di Muara Angke untuk tidak melakukan produksi. Variabel indikator ketersediaan bahan baku (X2.1) pada faktor lingkungan berada pada kategori tinggi, artinya pelaku usaha dalam menyediakan bahan baku untuk proses pengolahan ikan asin dapat dikatakan sangat baik, karena dengan adanya ketersediaan bahan baku yang merupakan salah satu modal utama dalam melakukan usaha dapat memudahkan pelaku usaha dalam melakukan proses pengolahan ikan asin. Dengan demikian, jika pasokan modal atau pasokan 
bahan baku meningkat maka berdampak pada peningkatan profit atau keuntungan yang akan digunakan kembali untuk pembentukan modal selanjutnya.

Dukungan penyuluhan dan pelatihan (X2.2) dalam penelitian ini diukur melalui seberapa sering pemerintah dalam memberikan penyuluhan dan pelatihan kepada para pelaku usaha ikan asin di Muara Angke. Berdasarkan hasil penelitian data menunjukkan bahwa indikator dukungan penyuluhan dan pelatihan berada pada kategori rendah dengan nilai rataan 2.13 , artinya penyuluhan dan pelatihan belum dapat dirasakan oleh sebagian besar pelaku usaha. Berdasarkan kenyataan di lapangan bahwa mayoritas pelaku usaha ikan asin mengaku tidak mendapatkan penyuluhan dan pelatihan mengenai kewirausahaan maupun tata cara pengolahan ikan asin tetapi mereka masih mampu melakukan proses pengolahan ikan asin melalui pengalaman yang didapatkan baik melalui keluarga ataupun kerabat. Hanya sebagian kecil responden yang menyatakan pernah mengikuti pelatihan mengenai cara pengolahan ikan asin dengan baik dan cara penanganan limbah ikan asin di Muara Angke yakni pelaku usaha yang melakukan usaha pengolahan ikan asin sejak tahun 1984. Oleh karena itu, dapat dikatakan bagi responden yang tidak pernah mengikuti pelatihan dan penyuluhan maka pengetahuan cara pengolahan ikan asin yang dimiliki hanya berasal dari orang tua, saudara ataupun kerabat. Selain itu mayoritas pelaku usaha ikan asin di Muara Angke menjalankan usaha karena ajakan oleh keluarga atau kerabat dan sebagian dari pada itu responden menjalankan usahanya turun temurun, sehingga pelaku usaha ikan asin yang menjalankan usaha secara turun temurun mendapatkan pengetahuan mengenai usaha dan cara pengolahan ikan asin berdasarkan dari pengalaman dan pengetahuan yang diberikan generasi sebelumnya.

Indikator bantuan modal (X2.3) pada faktor lingkungan berada pada kategori rendah dengan nilai rataan 2.09, artinya selama ini perhatian pemerintah berupa bantuan modal usaha memang belum dirasakan oleh para pelaku usaha ikan asin di Muara Angke, meskipun sebelumnya terdapat bantuan yang diberikan oleh pemerintah atau lembaga lainnya, namun hal tersebut belum terlalu berdampak kepada para pelaku usaha. Sementara pada dasarnya dengan adanya bantuan modal dapat meningkatkan skala usaha pelaku usaha ikan asin di Muara Angke. Oleh karena itu pemerintah diharapkan dapat menciptakan iklim usaha yang kondusif sehingga bantuan modal yang ada dapat dirasakan oleh pelaku usaha agar dapat menggerakkan perekonomian responden.

Indikator dukungan pemerintah (X2.4) pada faktor lingkungan berada pada kategori sedang dengan nilai rataan 2.97, artinya dukungan pemerintah seperti halnya promosi dan penyediaan informasi pasar belum dirasakan pelaku usaha secara signifikan namun dukungan pemerintah melalui bantuan penyewaan lahan yang dapat digunakan untuk melakukan proses pengolahan ikan asin dengan harga yang relatif murah sudah dapat dirasakan oleh para pelaku usaha ikan asin. Hal ini menunjukkan dukungan pemerintah yang dirasakan memadai bagi para responden. 
Kekompakan antar pelaku usaha ikan asin di Muara Angke (X2.5) juga merasa sangat memadai, hal ini ditunjukkan dari penilaian responden terhadap kekompakan antar pelaku usaha pada faktor lingkungan berada pada kategori tinggi dengan nilai rataan 3.88, artinya mereka menganggap bahwa kekompakkan diantara pelaku usaha itu sangat penting terutama dalam hal saling membantu dalam menjalankan usaha dan berbagi informasi mengenai harga dan sebagainya. Hal yang sangat baik dan dapat menjadi pondasi yang kuat dalam pengembangan dan keberlanjutan usaha ikan asin di Muara Angke. Kerjasama yang biasanya dilakukan oleh pelaku usaha ikan asin yakni meminjamkan sebagian tempat pengeringan kepada pelaku usaha lainnya yang sedang memproduksi ikan asin dalam jumlah yang banyak, selain itu proses penjemuran dan pengangkatan ikan dari tempat pengeringan juga dilakukan sebagian besar pelaku usaha jika tidak melakukan proses produksi. Melalui kerjasama antar pelaku usaha yang dijalankan pelaku usaha lebih efesien dan lebih mampu menghadapi ancaman, tantangan, hambatan, gangguan serta lebih menguntungkan. Hampir sebagian besar pelaku usaha ikan asin manyatakan bahwa banyak manfaat yang didapatkan melalui kerjasama antar pelaku usaha.

Secara umum faktor lingkungan rata-rata responden dalam menilai indikator pada faktor lingkungan belum dapat dikatakan baik. Hal ini merujuk pada hasil nilai rataan pada variabel indikator faktor lingkungan lebih banyak berada pada kategori rendah dan hanya indikator dukungan pemerintah dan kekompakan antar pelaku usaha yang memiliki skor penilaian indikator berada pada kategori sedang dan tinggi, sehingga dapat dikatakan bahwa beberapa variabel indikator belum mampu berkontribusi terhadap faktor lingkungan pelaku usaha ikan asin di Muara Angke dalam menjalankan usaha.

\section{Skor Indikator Perilaku Kewirausahaan Pada Usaha Pengolahan Ikan Asin}

Perilaku kewirausahaan pada penelitian ini direfleksikan oleh lima variabel indikator yaitu tekun berusaha, kreatif, inovatif, berani mengambil risiko dan bersikap mandiri.

Tabel 3 Penilaian pelaku usaha terhadap perilaku kewirausahaan

\begin{tabular}{ll}
\multicolumn{1}{c}{ Variabel Indikator } & Rataan \\
\hline Tekun Berusaha (Y1.1) & 3,46 \\
Kreatif (Y1.2) & 3,45 \\
Inovatif (Y1.3) & 2,77 \\
Berani Mengambil Risiko (Y1.4) & 3,88 \\
Bersikap Mandiri (Y1.5) & 4,40 \\
\hline
\end{tabular}
Keterangan: Rendah 1-2.33, Sedang 2.34-3.66, Tinggi 3.67 - 5

Tekun berusaha merupakan tingkat kegigihan pelaku usaha dalam menekuni usahanya dan kuat menghadapi kesulitan. Berdasarkan hasil penelitian dilihat dari segi perilakunya indikator tekun berusaha (Y1.1) berada pada kategori sedang dengan nilai rataan 3.46, artinya pelaku usaha ikan asin di muara angke masih memiliki dorongan yang kuat dalam melakukan usaha pengolahan ikan asin khususnya dorongan dari keluarga dan lingkungan sekitarnya. Hal ini menunjukkan responden tidak 
pernah menyerah, tetap tekun dalam berusaha jika mengalami kesulitan dalam melakukan proses pengolahan ikan asin serta kesabaran dalam menjalankan dan menghadapi kesulitan dalam berusaha.

Kreatif merupakan cara berfikir seorang wirausaha yang menghasilkan ide atau gagasan baru tanpa harus merealisasikan gagasan tersebut atau merupakan prasyarat inovasi. Variabel indikator kreatif (Y1.2) dalam penelitian diukur melalui seberapa kuat pelaku usaha berfikir dalam hal pengembangan usahanya, tanggap terhadap berbagai peluang yang ada disekitarnya serta cara berfikir pelaku usaha akan bagaimana memunculkan ide-ide baru untuk melakukan perbaikan kualitas produk yang disukai oleh masyarakat pada umumnya. Berdasarkan hasil penelitian data menujukkan variabel indikator kreatif pada perilaku kewirausahaan menunjukkan kategori sedang yakni 3.45, tingkat kreativitas pelaku usaha untuk mengembangkan usaha yang dijalankan cukup baik, namun pada kenyataan dilapangan hanya sebagian kecil pelaku usaha yang mampu memanfaatkan peluang yang ada salah satunya dengan membuka usaha pengolahan ikan lainnya seperti otak-otak, warung makan ikan dan lain-lain.

Inovatif merupakan aplikasi dari gagasan-gagasan kreatif. Suatu gagasan baru memiliki nilai apabila gagasan tersebut dapat diterapkan pada suatu produk. Berdasarkan hasil penelitian menunjukan persentase responden terhadap perilaku inovatif (Y1.3) berada pada kategori sedang dengan nilai rataan 2.77, artinya perilaku inovatif pelaku usaha ikan asin belum dapat diaplikasikan karena tingkat kretaivitas sebagian pelaku usaha juga masih belum mampu berfikir kearah pengembangan. Berdasarkan kenyataan dilapangan menunjukkan bahwa hal ini juga disebabkan oleh sebagian besar pelaku usaha masih mepertahankan cara produksi ikan asin secara tradisional, pelaku usaha ikan asin yang ada di Muara Angke menganggap bahwa teknologi untuk pembuatan ikan asin tidak menghasilkan tingkat kekeringan yang sesuai dengan menggunakan cara tradisional. Pelaku usaha ikan asin telah merasa puas akan hasil kinerja selama ini yang menggunakan cara tradisional sehingga cenderung tidak ingin melakukan inovasi karena tidak mempunyai cukup keberanian mengambil risiko dalam menerapkan inovasi yang prospeknya tidak mempunyai kejelasan hasil yang memuaskan salah satunya dengan penerapan teknologi pengering ikan. Selain itu salah satu faktor yang juga menjadi penghambat para pelaku usaha ikan asin tidak menerapkan teknologi dalam proses produksinya karena untuk menerapkan inovasi baru, misalnya teknologi dalam hal proses produksi, responden memerlukan penyuluhan, pelatihan serta pendampingan yang intensif dari pemerintah atau dinas terkait setempat untuk meyakinkan para pelaku usaha dalam penerapan suatu inovasi dalam usahanya. Selain itu responden perlu diberdayakan daya kreatif dan inovatifnya, misalnya melalui pelatihan dan pendidikan untuk mendapatkan seorang wirausaha yang inovatif karena perilaku inovatif tidak harus selalu menghasilkan sesuatu yang baru untuk menciptakan nilai tambah, tetapai dengan 
menerapakan teknologi sesuai dengan kebutuhan usaha telah dapat mencerminkan perilaku inovatif pada wirausahaan.

Berani mengambil risiko (Y1.4) merupakan kesediaan para pelaku usaha dalam mengambil risiko pada usahanya. Variabel indikator berani mengambil risiko dari segi perilaku berada pada kategori tinggi dengan nilai rataan 3.88, artinya mayoritas persepsi responden terhadap perilaku berani mengambil risiko menunjukan hasil yang cukup tinggi. Hal ini menunjukan bahwa pelaku usaha dalam menjalankan usaha pengolahan ikan asin sudah mampu memperhitungkan risiko yang mungkin timbul seperti fluktuasi kuantitas dan harga bahan baku, harga ikan mentah yang relatif tinggi serta kegagalan produksi. Namun salah satu perilaku dalam mengambil risiko yang masih rendah pada responden yakni mengambil risiko untuk modal besar demi keberhasilan usaha, sehingga skala beberapa responden tidak berkembang. Perilaku berani mengambil risiko sejalan dengan pengalaman seorang wirausaha dimana semakin banyak pengalaman dalam melakukan usaha pengolahan ikan asin maka hal tersebut dapat menjadi pengetahuan wirausaha dalam mengatasi risiko usahanya.

Bersikap mandiri merupakan sikap wirausaha yang tidak bergantung kepada pelaku usaha lainnya atau instansi pemerintah terutama dalam pengambilan keputusan pada usaha ikan asinnya. Persepsi pelaku usaha terhadap perilaku bersikap mandiri (Y1.5) berada pada kategori tinggi dengan nilai rataan 4.40, artinya perilaku bersikap mandiri ini terlihat dari keteguhan pelaku usaha yang terus menjalankan usaha pengolahan ikan asin dalam keterbatasan modal dan sarana prasarana. Meskipun adanya keterbatasan tersebut pelaku usaha ikan asin berusaha untuk tidak putus asa dalam menjalankan usahanya dan tidak bergantung kepada pihak lain dalam pengambilan keputusannya.

Secara umum rata-rata responden dalam menilai indikator pada variabel perilaku kewirausahaan dapat dikatakan cukup baik. Hal ini merujuk pada hasil nilai rataan pada variabel indikator perilaku kewirausahaan lebih banyak berada sedang dan dua indikator yang memiliki skor penilaian indikator berada pada kategori tinggi, sehingga dapat dikatakan bahwa beberapa variabel indikator mampu berkontribusi terhadap perilaku kewirausahaan pelaku usaha ikan asin di Muara Angke dalam menjalankan usaha.

\section{Skor Indikator Kinerja Usaha Pada Pengolahan Ikan Asin}

Kinerja usaha dalam penelitian ini adalah persentaseresponden atau pelaku usaha dalam menjawab pertanyaan mengenai kondisi usaha pengolahan ikan asin mereka saat ini. Pada penelitian ini kinerja usaha direfleksikan melalui empat variabel indikator yakni perluasan pemasaran, peningkatan penjualan, keunggulan bersaing dan kepuasan pelanggan.

Tabel 10 Penilaian pelaku usaha ikan asin terhadap kinerja usaha

\begin{tabular}{ll}
\hline \multicolumn{1}{c}{ Variabel Indikator } & Rataan \\
\hline Perluasan pemasaran (Y2.1) & 3,15 \\
Peningkatan penjualan (Y2.2) & 3,90 \\
Keunggulan bersaing (Y2.3) & 3,44
\end{tabular}


Kepuasan pelanggan (Y2.4) 2,94

Keterangan: Rendah $1-2.33$, Sedang $2.34-3.66$, Tinggi $3.67-5$

Berdasarkan hasil penelitian, data pada tabel 10 menunjukkan variabel indikator perluasan pemasaran (Y2.1) terhadap kinerja usaha berada pada kategori sedang dengan nilai rataan 3.15, artinya pelaku usaha terhadap meningkatnya wilayah pemasaran menunjukan kecenderungan yang cukup baik. Hal tersebut terjadi karena pelaku usaha ikan asin menganggap perluasan pemasarannya sudah tercapai dengan meningkatnya jumlah tengkulak yang datang dari berbagai daerah untuk membeli ikan asin di Muara Angke. Pemasaran ini dilihat dari meningkatnya jumlah wilayah pemasaran, serta peningkatan jumlah konsumen. Hal ini dibuktikan dari meskipun wilayah pemasaran hanya pada satu pasar saja yakni dilokasi tempat produksi ikan asin tetapi dapat dilihat dari banyaknya tengkulak yang datang dari berbagai daerah dan hasil produksi ikan asin juga tidak pernah ada yang tidak terjual. Semakin berkembangnya usaha yang dijalankan, dengan meningkatkan perluasan pemasaran dapat memberikan efek meningkatnya keuntungan. Hal inilah yang membuat para pelaku usaha ikan asin tetap bertahan menjalani usaha ini dalam jangka waktu yang bertahun-tahun, meskipun terkendala oleh kenaikan kuantitas dan harga bahan baku yang tidak stabil. Namun dengan keyakinan dan kemauan berusaha para pelaku usaha pengolahan ikan asin mampu menyiasatinya dan dapat bertahan menjalankan usaha hingga bertahun-tahun.

Peningkatan penjualan merupakan keinginan setiap wirausaha, dimana peningkatan volume penjualan juga merupakan salah satu indikator kinerja usaha karena peningkatan volume penjualan akan meningkatkan pendapatan dan keuntungan usaha. Indikator peningkatan penjualan (Y2.2) berada pada kategori tinggi dengan nilai rataan 3.90, artinya peningkatan penjualan belum dirasakan oleh semua responden atau pelaku usaha khususnya yang memiliki skala usaha atau jumlah produktivitas yang relatif sedikit. Selain itu peningkatan volume penjualan belum terlalu dirasakan oleh mayoritas pelaku usaha ikan asin di Muara Angke karena kegiatan usaha ini selalu dekat dengan ketidakpastian dengan adanya fluktuasi jumlah bahan baku ikan dan garam, faktor cuaca yang juga dapat mempengaruhi jumlah dan harga ikan mentah. Akan tetapi pelaku usaha yang memiliki skala usaha yang besar dan jumlah produksi juga besar, peningkatan penjualan sangat dirasakan dan berdampak pada besarnya pendapatan dan keuntungan yang diperoleh.

Keunggulan bersaing merupakan kemampuan pelaku usaha ikan asin dalam bersaing yang dilihat berdasarkan kemampuan para pelaku usaha ikan asin bersaing dengan pelaku usaha ikan asin lainnya dengan ditunjukkan melalui jumlah produktivitas yang meningkat dari waktu ke waktu, harga produk ikan asin yang jauh lebih bersaing, serta menjaga kualitas ikan asin yang diproduksi. Berdasarkan hasil penelitian data menunjukan bahwa variabel indikator keunggulan bersaing (Y2.3) berada pada kategori sedang dengan nilai rataan 3.44, artinya produk ikan asin masih memiliki 
keunggulan bersaing yang cukup baik. Jumlah hasil produksi mayoritas pelaku usaha ikan asin di Muara Angke mengalami peningkatan meskipun pada waktu-waktu tertentu hasil produksi dapat turun dikarenakan bahan baku yang sulit didapatkan selain itu harga produk ikan asin ini memiliki harga yang jauh lebih bersaing jika dibandingkan dengan produk olahan ikan lainnya. Selain itu pada kenyataannya di lapangan yang mengakibatkan indikator kunggulan bersaing berada pada kategori sedang diduga karena produk ikan asin belum memiliki label dan kemasan yang menarik sehingga ketertarikan konsumen pada produk ini belum baik khususnya konsumen pada tingkat ekonomi menengah keatas.

Kepuasan pelanggan merupakan kemampuan pelaku usaha ikan asin dalam hal memberikan kuantitas dan kualitas produktivitas ikan asin. Variabel indikator perluasan pemasaran (Y2.4) berada pada kategori sedang dengan nilai rataan 2.94. Namun berdasarkan kenyataan di lapangan bahwa kepuasan pelanggan terhadap hasil produksi ikan asin para pelaku usaha dari Muara Angke belum menunjukkan hasil yang baik, karena masih banyaknya para pelaku usaha yang melakukan pengolahan ikan asin dengan kadar keasinan ikan yang tidak pas, meskipun kejadian ini tidak sering berulang. Selain itu masih adanya responden yang masih kurang terampil dalam mencari informasi pasar, sehingga pada dasarnya responden lebih pasif dan konsep penjualan yang digunakan adalah yang penting laku atau terjual, dan belum terlalu memikirkan kualitas dari ikan asin itu sendiri serta tidak mementingkan kepuasan konsumen itu sendiri. Konsep tersebut yang menyebabkan sulitnya usaha ikan asin di Muara Angke berkembang.

Secara umum rata-rata responden dalam menilai indikator pada variabel kinerja usaha dapat dikatakan cukup baik. Hal ini merujuk pada hasil nilai rataan pada variabel indikator perilaku kewirausahaan lebih banyak berada sedang dan satu indikator yang memiliki skor penilaian indikator berada pada kategori tinggi, sehingga dapat dikatakan bahwa beberapa variabel indikator mampu berkontribusi terhadap kinerja usaha pelaku usaha ikan asin di Muara Angke dalam menjalankan usaha.

\section{KESIMPULAN}

Karakteristik pelaku usaha ikan asin di Muara Angke secara umum antara lain: (1) Mayoritas pelaku usaha berjenis kelamin laki-laki dan usaha pengolahan ikan asin merupakan mata pencaharian utama; (2) Tingkat pendidikan mayoritas lulusan SD; (3) mereka memiliki pengalaman yang cukup dalam melakukan usaha pengolahan ikan asin, (4) pendapatannya sebagian besar sudah mampu memenuhi kebutuhan sehari-hari mereka (5) Modal usaha didapatkan merupakan modal pribadi; (6) taraf hidup dan kesejahteraan pelaku usaha ikan asin pada umumnya masih rendah, dikarenakan skala usaha yang masih kecil, serta mayoritas pelaku usaha ikan asin hanya berorientasi pada pemenuhan kebutuhan sehari-hari. 
Arnis N : Karakteristik Pelaku Usaha Ikan Asin di Muara Angke

\section{DAFTAR PUSTAKA}

Krisnamurthi, B. (2001) Agribisnis. Bogor: Yayasan Pengembangan Sinar Tani.

Krueger, N., Reilly, M. and Carsrud, A. (2000) 'Competing Models of Entrepreurial Institutions’, Journal of Business Ventering, 15(6), pp. 411 - 432.

Partomo TS, S. A. (2002) Ekonomi Skala Kecil/Menengah dan Koperasi. Jakarta: Ghalia. 